\title{
REVERSE LOGISTICS PROCESSES IN INDUSTRIAL WASTE MANAGEMENT AS AN ELEMENT OF SUSTAINABLE DEVELOPMENT
}

\author{
Marta Starostka-Patyk ${ }^{l}$ \\ Janusz K. Grabara ${ }^{2}$
}

\begin{abstract}
This article has a brief introduction about reverse logistics usage in waste management. Then Authors proposed own elaborated descriptive model of reverse logistics processes in enterprises managing industrial waste. There was a research made in Poland in Silesia region on six different enterprises managing industrial waste, so model is based on reverse logistics literature studies and practical activities of waste management in enterprises managing industrial waste. The paper presents very clear the role of reverse logistics processes in enterprises managing industrial waste. It shows very interesting connection between logistics and waste, what is an interesting element of sustainable development conception for achieving ecological goals.
\end{abstract}

Key words: reverse logistics, waste management, industrial waste, sustainable development.

JEL codes: $M 10$, M11, M12.

\section{Introduction}

Sustainable development is multi-layered nature of the plane by combining such as ecology, philosophy, culture, society, economy, politics, technology and economics (Ślusarczyk B. and Modrak V., 2010). Its practical aspect is the introduction of governance between these planes. From a logistics perspective one of the elements in order to maintain sustainable development is to address the problem of waste and this is logistics management of waste streams. Noting the global approach to the problem of waste is a noticeable trend increasingly greater use of logistics management processes of waste streams to meet the principles of sustainable development, while combining ecological and economic objectives. Ecological purpose stresses the relationship between logistics and the environment, which is to protect natural resources and reducing pollution arising from the presence of waste and the economic objective is clear from the essence of logistics and to reduce logistics costs while improving service levels of reverse logistics and waste management. In the long run, these objectives are most consistent, and strive to achieve them allow to obtain positive results at both ecological and economic. Positive results of the reverse logistics in waste management in business practice gives hope to popularize this concept, which, in a measurable way can contribute to the practical implementation of the philosophy of sustainable development, both at the level of individual enterprises and global supply chains.

\section{Literature review}

Reverse logistics is primarily used as a tool for management in an appropriate manner all kinds of waste. Waste, and the consequences associated with their presence in the environment in recent years become a major problem in the environmental field. Hence, interest in the subject comes to waste management increasingly wider scale. Significant progress is observed in advanced technologies that not only enable the minimization of pollutants generated, but also allow for redevelopment or disposal of waste. The Waste Act defines it as: "all items, and solids and liquids other than water management resulting from business activities or human existence and unsuitable

\footnotetext{
${ }^{1}$ Czestochowa University of Technology, The Management Faculty, Armii Krajowej 19B, 42-200 Czestochowa.

${ }^{2}$ Czestochowa University of Technology, The Management Faculty, Armii Krajowej 19B, 42-200 Czestochowa.
} 
in a place or time, which they arise; as waste is also considered sludge". In addition, has been clarified that it referred to as municipal waste is "solid and liquid wastes generated by households, in public buildings and public services, including rubbish collected in cesspools, abandoned motor vehicle wrecks and waste, street, and industrial waste is any waste "arising from the conduct of any business" "Municipal waste is an integral part of society, but it is industrial waste require special attention in the field of waste management, because they have far more negative impact on the environment.

Waste management is a fundamental task of reverse logistics. Its processes mainly concern the appropriate organizations how to deal with waste ${ }^{4}$. Waste management can be viewed in terms of process and the object.

Objects of control in the process term are ${ }^{5}$ :

- Prevention of waste, including became obvious by the rationalization of production and consumption;

- Generation of waste, including the design of products taking into account the rest mass of recycled after use;

- Separate collection, mainly by the segregation of waste at source;

- Recovery of matter and energy contained in waste, or waste recycling in whole or in part, or recovery from waste substances, materials or energy and their application;

- Recycling, a recycling of substances or materials in waste in the production process in order to obtain the substance or material the original or other purposes;

- Disposal of waste consisting of being subjected to processes of biological, physical or chemical treatment to bring about a state that does not pose a risk to human life, health or the environment.

In terms of the preferred process is to prevent waste, became obvious in the rationalization of production and consumption, and became obvious and the least desirable waste disposal ${ }^{6}$.

Breakdown of facilities management subsystems depends on the source and nature of waste. Thus, in the present system it is possible to distinguish municipal waste, industrial waste electrical and electronic equipment, end of life vehicles, hazardous wastes and other wastes, which include among others sewage sludge, waste from construction, medical and veterinary waste ${ }^{7}$.

Reverse logistics focuses its attention on the waste, "the materials arising from any human activities or natural forces, as they usually unintentionally, though difficult to avoid the effect. In other words, waste is an object or material that cannot be used at all or in full accordance with its original purpose in a given place and at any given time ${ }^{\prime 8}$. Wastes in terms of physico-chemical, divided into solid, liquid and gas. However, in the place of their creation, share them on municipal and industrial wastes. The Waste Act defines municipal waste as the waste arising from human existence, while industrial waste, as the resulting business. In addition, the group singled out is also a hazardous waste, which is mainly industrial waste. Municipal waste is any waste generated by

\footnotetext{
${ }^{3}$ The Waste Act, Dz. U. z 2001, nr 62, poz.628.

4 See: Bloemhof-Ruwaard J.M., Fleischmann M., van Nunen A.E.E.: Distribution Issues in Reverse Logistics Management, Report Series 57, Erasmus University Rotterdam, Netherlands, 1998; Por. Beullens P., Van Oudheusden D., Cattrysse D.: Bi-destination waste collection: impact of vehicle type and operations on transportation costs. Proceedings Second International Working Seminar on Re-use, TU Eindhoven, The Netherlands, 1999; Por. Kleineidam U., Lambert A.J.D., Blansjaar J., Kok J.J., van Heijningen R.J.J.: Optimising product recycling chains by control theory, [w] International Journal of Production Economics, nr 66(2), 2000; Por. Toktay L. B., Wein L.M., Zenios S.A.: Inventory Management of Remanufacturable Products, [w] Management Science, nr 46(11), 2000.

${ }^{5}$ Poskrobko B., (red.), Zarządzanie środowiskiem. PWE, Warszawa 2007, s. 210.

${ }^{6}$ Ibidem, s. 211

${ }^{7}$ The comprehensive classification is done in Commission Decision 2000/532/WE on 3rd May 2000, which set the waste list, and In Poland this is Act made by Environment Ministry on 27 September 2001, about the waste catalogue.

${ }^{8}$ Ambrożewicz P., Zwarty system zagospodarowywania odpadów. Wyd. Ekonomia i Środowisko, Białystok 1999, s. 12.
} 
households and the waste does not contain hazardous waste from other waste, which because of its nature or composition is similar to waste from households ${ }^{9}$.

From the perspective of the business scope of the reverse logistics used for waste disposal include ${ }^{10}$ :

- The classification of waste by the possibility of reuse and of the danger they may cause;

- Purchase, storage, sorting, transformation, transport, processing, adaptation, recovery, processing, storage and sale of materials to be removed;

- Other activities necessary to eliminate waste, such as export of goods or unnecessary scrapping of used equipment.

Since the reverse logistics can be used in almost every industry, it can occur in many forms, depending on the area of deployment. Here, the mechanism is dependent on the application proper use of one of the principles of reverse logistics $6 R$ is: "recognition, recovery, review, renewal, removal, reengineering" "I In the case of an effective waste management, which is consistent with the above-mentioned assumption of environmental management, reverse logistics takes the form of concepts, where the following priority actions are: "minimization, reuse, recycling, incineration, depositing in landfills" ${ }^{\prime 2}$. A slightly different arrangement of reverse logistics hierarchy of waste streams in waste management has been proposed in another study, where "the most important action is to re-use, then processing, recycling, waste-related with energy recovery and eventually depositing in landfills" 13 .

In interpreting these measures, companies should first make every effort to ensure that waste is suitable for reuse. This means that waste products can be used in the same or a different purpose, but without additional specialized treatment. Then, if re-use for various reasons it is not possible, the waste can be processed. This means that the products or parts can be reused, but in the end it is necessary to take additional actions such as repairs, etc. Unfortunately, the use of this option can often mean a lower quality final product, which is the cause of the inability of treatment products which have been renovated as a product of first quality. A very popular activity in the reverse logistics is recycling, which, however, requires additional and advanced waste treatment. Products must be taken apart and inspected because of the quality of components, which can then be re-used or use as raw materials for manufacturing the same, similar or different product. If the wastes are not suitable for recycling processes, they can be used to process them in a way to regain energy. Large companies may manage the waste so if they have special facilities for these activities. Then the energy recovered from waste, for example, can power the production process, which saves raw materials intended for the original power supply. Last action - depositing in landfills is the least effective method of waste managing in reverse logistics, however, the most widely used. It is highly economical, since it involves a loss of materials, as well as being extremely harmful to the environment.

These activities clearly underline the need for the use of reverse logistics for waste management, as well as show that the logistics management of waste streams is a connection between waste and their managing and recovery ${ }^{14}$.

In the European Union countries the hierarchy of reverse logistics in waste management is divided against three-level waste management hierarchy. This system systematizes procedures for the waste generated by businesses and individuals. The first level is to reduce waste at source, a place of their formation, and is associated with methods permitting to avoid creating waste. If

\footnotetext{
${ }^{9}$ The Waste Act, Dz. U. z 2001, nr 62, poz.628.

${ }^{10}$ Kramer M., Strebel H., Buzek L., Międzynarodowe zarządzanie środowiskiem. Tom III: Operacyjne zarządzanie środowiskiem w aspekcie międzynarodowym i interdyscyplinarnym. Wyd. C.H. Beck, Warszawa 2005, s.60.

${ }^{11}$ Guitini R., Introduction to reverse logistics. [w] Total Quality Environmental Management 3.3., 1996, s. 83

${ }^{12}$ Welford R., Gouldson A., Environmental Management and Business Strategy. Pitman, London, 1993, s.32

${ }^{13}$ Carter C., Ellram L., Reverse logistics: A review of the literature and framework for further investigation. [w] Journal of Business Logistics, 1998, s. 69.

${ }^{14}$ Rogers D., Tibben-Lembke R., Reverse logistics challenges. University of Nevada, Reno, 1999, s. 87.
} 
operating at this level is not possible in the next order it is attempting to retrieve the waste for recycling. Only in the further option is the final disposal of waste.

To correctly establish a strategy for waste management is necessary to carry out a thorough analysis of the sequence, the analysis of different options and the analysis of certain options ${ }^{15}$.

The concept of reverse logistics based on four basic principles that are structured by the validity as following ${ }^{16}$ :

- Materials used in the production should be recycled instead of new materials,

- Used materials should be organic,

- Recycled materials should be re-used (primarily packaging)

- Materials should be recovered in different ways and from different sources as widely as possible.

These actions are considered by the company for not only expensive but also require a sizeable commitment. The very initial phase of product design should take into account the requirements related to its re-development. Thus, all of the reverse logistics processes are forcing the companies referred to involving the consequences of their business productivity. A welldesigned products that meet the requirements of reverse logistics, are products that can be easily dismantled and will be suitable for recycling or re-use, require a detailed analysis of its life cycle, the influence of environmental factors on the production, use by the customer and how they get rid of it. Equally important is close cooperation with suppliers and subcontractors, aiming at gaining access to raw materials and suitable for reuse ${ }^{17}$.

In the mid-nineties was defined and specified product recovery management by setting specific recovery options ${ }^{18}$ :

- Direct reuse (re-sale);

- Managing product recovery (repair, restoration, processing, recycling);

- Waste management (burning or non-payment on the ground).

Through such arrangements have been characterized reclamation options, namely the characteristics of the recovery process of the products, while maintaining the quality of both the process and the final product. It was also the approximate date of the reverse distribution, which means the direct recovery values.

Very important are also those associated with the diversity of logistics management systems, waste streams, which they do very specific and useful. Among them can be distinguished ${ }^{19}$ :

- The motivation (economic and ecological);

- Type of articles (spare parts, packaging materials, finished products);

- The form of reuse (direct reuse, repair, recycling and processing) and the form of processes collection, testing, sorting, transport and processing);

- Involved participants (members of the traditional channel or a specified part).

The literature also found a different approach to reverse logistics using the recycling of used goods as inspiration for the formation of the following types of inverse channels ${ }^{20}$ :

\footnotetext{
${ }^{15}$ Korzeń Z., Ekologistyka. ILiM, Poznań 2001, s. 59.

${ }^{16} \mathrm{Wu}$ H.J., Dunn S.C., Environmentally Responsible Logistics Systems, [w] International Journal of Distribution \& Logistics Management (25); 1995 s. 196; Por. Tsoulfas G., Pappis C.: Application of environmental principles to reverse supply chains. [w] Proceedings of the $3^{\text {rd }}$ Aegean Conference, 2001

17 Grabara J., Ewolucyjny Charakter Systemów informacyjnych na Przykładzie Informatycznego Wspomagania Logistyki Odwrotnej, [w] Informatyka w gospodarce Globalnej. Problemy i Metody; 2003, s. 64.

18 Thierry M., Salomon M., van Nunen J. A. E. E., van Wassenhove L. N., Strategic issuesin product recovery management. California Management Review, 1995, 37(2), s. 124.

${ }^{19}$ Fleischmann M., Bloemhof-Ruwaard J. M., Dekker R., van der Laan E. A., Van Nunen J. A. E. E., van Wassenhove L. N., Quantitative models for reverse logistics: A review. European Journal of Operational Research, 103, 1997, s. 10.
} 
- Integrated into the processor;

- The flow of waste;

- Specialized dealers inverse;

- Traditional wholesale and retail merchants;

- Timed, easy flow.

Some of the participants are responsible for the reverse logistics chain, or organize it, while others only complete certain tasks in that chain. Extremely important is the role of the final participant in the chain, because without it, all of the processes of recovery values would make no sense. The next group of participants involved in the reverse logistics processes, such as collection and processing, are independent brokers, specialized organizations dealing with the recovery value, the service provider of reverse logistics, municipal enterprises engaged in waste collection, private and public foundations set up to deal with the recovery value. Each participant, however, has other goals in the chain, and often causes the opposite reaction is competitive.

Use reverse logistics processes for waste management, particularly hazardous or industrial waste significantly increases the efficiency and productivity associated with these activities. It is important that companies engaged in the business of waste managing seek to implement these processes in order to improve its own functioning.

\section{Research methodology}

Since the reverse logistics is not a widespread concept that requires specific knowledge of waste management, and is relatively expensive, in practice it is usually implemented partially and in a few companies, and most are not implemented at all. Therefore, companies that produce waste, outsource managing them to specialized bodies. It is these firms, companies managing industrial waste and more specifically in the Silesia region ${ }^{21}$ are objects that are utilized in this research work.

The research is the reverse logistics processes in six companies managing industrial waste in the Silesia region. Two of them are dealing with complex industrial waste as well and utilities across the country, with several branches in the province of Silesia. One is a company specializing exclusively in the management of industrial waste produced in the Silesian branch of the Lower Silesia province, and the other three are small companies, professional managing industrial waste and supporting local, which is located within a few to several kilometers from their waste producers. The activities of these companies have been analyzed in the five-year period in 2004-2008.

Characterizing the activity of enterprises should pay attention to the specificities of their activities. Due to the fact that the waste management industry takes into account many of the principles and rules of law, it is not possible to harmonize. It is also closely linked to the diversity and specificity in the production of clients served, so that any one customer is an individual. In view of the customer aspect of individuality, research, linked to the reverse logistics, is presented in this work were carried out taking into account only the regular customers of these companies.

Given these distinctions, in order to clarify the descriptive processes of reverse logistics, it is possible to build a general descriptive model of the businesses performance using the concept of reverse logistics.

For detailed discussion and analysis of reverse logistics processes occurring in the enterprises managing industrial waste authors have developed on the basis of own research descriptive

\footnotetext{
${ }^{20}$ Fuller D. A., Allen J., A typology of reverse channel systems for post-consumer recyclables. [w] J. Polonsky and A. T. Mintu-Winsatt, editors, Environmental marketing: strategies, practice, theory and research. Haworth Press, Binghamton, NY, 1997, s. 36.

${ }^{21}$ Kot S., Foreign Direct Investment in Silesia Region. W:The Challenges for Reconversion. Innovation - Sustainability - Knowledge Management. Ed.by Piotr Pachura. ISI Pierrard, HEC du Luxemburg, Virton, 2006.
} 
model. It is based on the solutions presented in the literature on reverse logistics ${ }^{22}$. This model is a development of reverse logistics together the concepts presented in the literature with the practice of entrepreneurial activity managing industrial waste. Its graphical presentation shows figure 1.

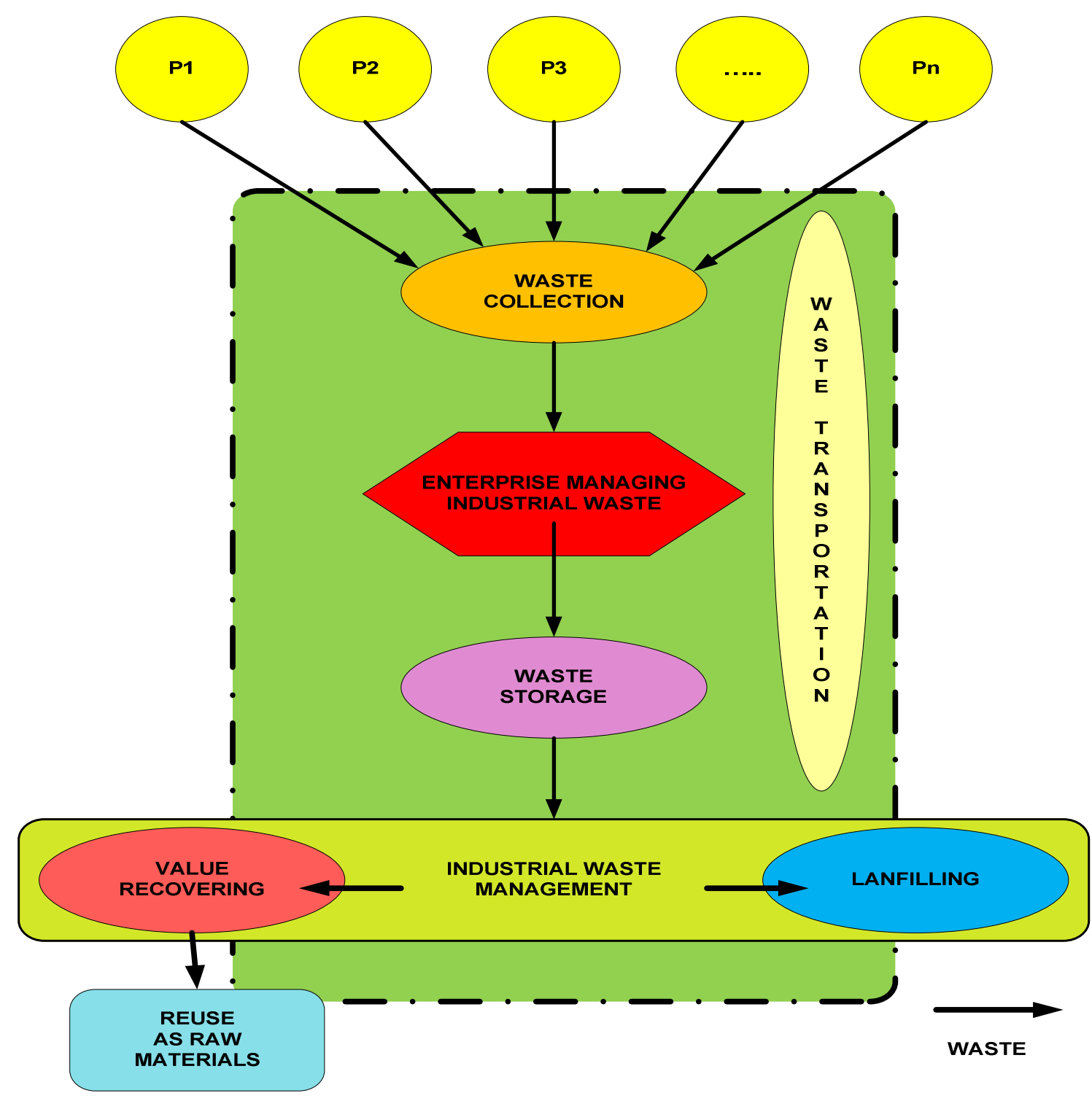

P1, P2, P3...Pn - customers (enterprises generating industrial waste)

Fig. no. 1. Processes of proper waste disposal realized by enterprise managing industrial waste

Source: Authors own elaboration

22 Cf. Carter C.R., Ellram L.M., Reverse logistics: a review of the literature and framework for future investigation.Journal of Business Logistics 19 (1), 1998, s. 85-102; Jahre M., Household waste collection as a reverse logistics channel: a theoretical perspective. International Journal of Physical Distribution and Logistics Management 25 (2), 1995, s. 39-55; Koo J.K., Shin H.S., Yoo H.C., Multiobjective siting planning for a regional hazardous waste treatment center. Waste Management and Research 9, 1991, s. 218-250; Kroon L., Vrijens G., Returnable containers: an example of reverse logistics. International Journal of Physical Distribution and Logistics Management 25 (2), 1995 , s. 56-68; Zografos K.G., Samara S.S.A., Combined location-routing model for hazardous waste transportation and disposal. Transportation Research Record 1245, 1990, s. 52-59; Hu T-L., Sheu J-B., Huang K-H., A reverse logistics cost minimization model for the treatment of hazardous wastes. Transportation Research part E, 38, 2002, s. 457-473. 
The concept developed by the authors is presented in the form of natural flow pattern of industrial waste and explains the essence of the individual processes and their relationships. In addition, it should be noted that the presented model is suitable for industrial and hazardous waste. Treatment of municipal waste would be presented in another way. In addition, enterprises engaged in waste management are generally geared to receive industrial and hazardous waste, which automatically eliminates the need for matching processes to the municipal solid waste.

The marks P1, P2, P3, ... and Pn, mean individual customers who use the services of the company managing waste. Customers are small, medium and large manufacturing companies, service and trade. These companies produce industrial and hazardous waste, in accordance with the Law on Waste transmit a specialized company which carries out the land use in order to minimize the negative impact on the environment. Transfer of waste from the customer to the company managing industrial waste is also their entry into the reverse logistics processes.

Production business, commercial or service, if generate any waste, are required by Polish law into their records and to determine an appropriate plan for their development. Since the activities related to waste management is costly and often time-consuming, companies will instead lead them yourself, arrange for them to specialized bodies. Companies that want to use the services of a specialized entity in order to care for the environment (and as required by law) must possess the appropriate documents and provide a list of the types of waste generated, together with their mass. Company managing waste on this basis shall quote management of this waste and provide an estimate, or valuation of their services, which may be accepted or rejected by the customer. If the client does not agree to the conditions it is forced to find another company with a more favorable deal. But if both sides recognize the established conditions to be satisfactory - sign an agreement. At the conclusion of the agreement and start its implementation in industrial waste management company begins to implement the processes included in the system of reverse logistics.

However, before the industrial waste will be transferred to a company specializing in process management, are subject to segregation. According to Act on Waste, the company producing industrial and hazardous wastes are required for their self-segregation, and therefore to the business they get waste manage, distinguishing between the different types of waste codes corresponding to the Waste Catalogue. Of course, the waste management company can assist its customers in these activities by providing various types of containers, or containers for all kinds of waste, and also provide information on the most advantageous ways of segregation and temporary storage.

Sorted industrial waste are transferred to companies managing waste. In practical terms, the batch of waste is usually the case when the manufacturer will bring together the appropriate amount of a given type of waste. It is for him so advantageous that, in ensuring full loading the car transporting the waste reduces transportation costs incurred. However, this solution involves the need to have a dedicated place where it is possible to temporary storage of waste in accordance with the principles of storage in order to collect the party providing economically efficient loading. If there are large quantities of waste and they have a lot of weight, then the frequency with which they receive is greater. If the amount of waste is small and has a small mass that can be received less often. This is closely connected with the transport of waste, where transport costs are related to the carrying capacity of vehicles carrying waste.

With an appropriate weight of such waste, contact the manufacturer with the company managing industrial waste and inform its employees about the need to receive that waste. This moment of contact between companies can be considered as the beginning process of reverse logistics.

Receive industrial waste from its manufacturer means the process of waste collection by the company managing waste. If waste producers do not always have the possibility of their temporary storage in order to collect a full load, or collect a full load is not possible during one year (a time period of storage of waste is in compliance with the law), that the company managing waste have to 
collect them so to ensure full capacity of their shipments while it did not exceed the storage capacity. Only such activities guarantee its rationality and economic efficiency.

Accordingly, industrial waste collected from their manufacturers are transported to a warehouse of company managing industrial waste, which are exactly recorded and temporarily stored in a designated place, until meet for the specified weight, suitable for efficient transfer of waste to economic recovery or storage. If the load of waste received from the client is full is also transported to the warehouse company, with the difference that depending on the type of waste may not necessarily be there, its discharge, and can only be decided on the further handling of the transport and transfer of waste for recovery or storage. However, all waste collected from customers in the first instance are moved to a warehouse of company managing waste where they are subjected to the final segregation - the waste that is not suitable for reuse and disposal will be sent to the landfill, and those which can be recovered. In addition, waste is stored in the warehouse are often subjected to segregation in the pre-treatment processes such as crushing and baling, which in subsequent phases allows for easier transportation and disposal of, or recovery. They are also necessary processes for the donation of waste at the landfill, because they allow a significant reduction in the volume of waste. In addition, the landfill does not accept hazardous waste, so if any, and are not suitable for recovery, it must first be disposed of and only in the state delivered to the landfill. All these processes may also take place at the client, it is no longer dependent on whether he has adequate technical and technological capabilities.

Generally, the type of waste storage is usually no longer than until the collection of waste from manufacturers of mass allowing for full load transport. Then, it is possible to remove it from the record storage and transmission to the appropriate installation or recovery devices, or disposed of by landfill. Companies managing industrial waste shall seek to minimize the process of storage, mainly for financial reasons but also due to the fact that certain types of waste during the "aging" in the magazine may well lose its value (for example, wet paper, rusted scrap, etc.).

Analyzing the process of waste management, from the perspective of the company managing industrial waste, there are two possibilities in this respect: the transfer of waste for recovery, or deposit them in a landfill. Currently noticeable is a growing trend toward seeking ago to manage the waste industry by exposing their recovery. This is beneficial from the point of view of environmental protection, because the smaller mass of waste in arrears on the ground, and from an economic point of view - allows for recovery of recyclable materials, which require much lower amounts of money to buy them than the original materials, while there may have up to $100 \%$ of the original material properties. Processes related to the recovery of industrial waste ending phase waste management in the logistics management process waste streams, and the resulting secondary raw materials these processes are part of the input reverse supply chain and are distributed to customers having a demand for these materials. Reverse distribution can be regarded as the last stage of the logistics management system for industrial waste streams, it being pointed out that not every person working on tasks that the system carries out the tasks associated with the distribution.

Unfortunately, currently does not have the possibility of transferring all types of waste for recovery, because the recovering plant and equipment often does not correspond to technical and technological requirements necessary for the recovery of value from certain types of industrial waste. In addition, installations and equipment for recovery are usually designed to recover the value of one or at most a few different types of waste. By submitting the waste so it is necessary for recovery after their delivery services are often much broader geographic area, while dividing the types of waste required for an installation or recovery device, which can substantially increase the costs associated with storing and transporting. Often, the waste may be recovered even though it goes into landfill due to the excessive costs associated with their recovery. Therefore, observing the activities of companies managing industrial waste is noticeable that, despite many positive developments in this field is still not the majority collect waste from their manufacturers shall be deposited in landfills of industrial waste. 
In practice, usually the company managing industrial waste co-operates with a single, selected the site (in some cases can be greater cooperation with more than one landfill, for example when the quantity of deposited waste may exceed the specified capacity and designated for landfill disposal or landfill is not conditions and opportunities to adopt certain types of waste). Such cooperation is advantageous because of the possibility to negotiate the conditions of depositing waste on the site, including the negotiations on the financial aspects in the first place.

\section{Conclusions}

It should be noted that the formation of reverse logistics processes in case of waste streams is carried out through the course of its various activities, depending on the expected value of the recovery of a specific product. Admission application of the principles of reverse logistics in waste management is the existence of adequate logistics system. The system approach is key to understanding the principles of logistics and can be viewed spatially, organizationally and IT.

Logistically integrated waste management system can be identified and constructed in terms of functional areas. Functional areas stands out due to the activity which is related to real sphere, i.e. the formation of waste being transported to waste facilities, storage, use and destruction of economic and regulatory realm, that is, activities related to regulating and controlling the system.

The main components of logistically integrated waste management system may include subsystems: waste collection, export of waste, and commercial use, processing or disposal of waste, according to a presentation hierarchy of values in the recovery of waste, including reuse, remanufacturing, recycling and storage.

The main determinants of the functioning of an integrated reverse logistics system of waste management are: the number, nature and spatial distribution of waste; degree, regularity and dynamics of the generation of waste, adopted rules for the implementation of environmental protection, urban spatial factors: the structure and shape the region's settlement network, the possibility of the location of system objects, routes communication, the spatial structure of economic activity, etc., overall standards and local (regional and local) requirements for allowable loads of the environment.

Expression of the structure of the system to adapt to the implementation of tasks falling to it is its efficiency, reliability, availability to users, the operating bandwidth (the frequency corresponding export and processing of waste from the area), and vulnerability to changes in the system, the degree of compliance with regulatory requirements and the impact of system objects on the environment.

Logistics in the field of waste management primarily emphasizes the ecological aspects. It is however foreseen that the development of logistics systems in the area of treatment will stimulate factors of marketing. Observed among customers because more and more inclined to buy a product, which is dominated by elements coming from the recovery and suitable for reprocessing. It can therefore be concluded that the logistics management of waste streams will be more widely and readily used by various operators. This will be the result of an increase public awareness of environmental issues and were forcing from the competitive market, which should be an ever larger scale appear in products and other goods produced with a focus on re-use or recover the value resulting from the use of waste future.

Summarize, it is necessary to notice how important in present times proper waste management is. Such effective tool as reverse logistics for waste management gives a big support for companies and entities producing waste. It has a very positive impact on sustainable development because that kind of activity allow for protection natural environment. Even if the costs of waste management and reverse logistics are still quite high, it is very important to spread such good solutions in literature, and also imply into practice.

\section{References}


1. Ambrożewicz P., Zwarty system zagospodarowywania odpadów. Wyd. Ekonomia i Środowisko, Białystok 1999, s. 12.

2. Beullens P., Van Oudheusden D., Cattrysse D.: Bi-destination waste collection: impact of vehicle type and operations on transportation costs. Proceedings Second International Working Seminar on Re-use, TU Eindhoven, The Netherlands, 1999.

3. Ślusarczyk B., Modrak V. (ed.), The Role of Business in Achieving Sustainability. Part 2: Implication for Industry. Wyd.Techn.Univ.Kosice, Presov, 2010. 